\title{
Translation Strategies Applied in English-Arabic Translation: A Case of a Website Article
}

\author{
Dalia Abdelwahab Massoud Abdelwahab ${ }^{1}$ \\ ${ }^{1}$ Sciences and Arts College, Northern Border University, Turaif, Saudi Arabia \\ Correspondence: Dalia Abdelwahab Massoud Abdelwahab, Sciences and Arts College, Northern Border University, \\ Turaif, Saudi Arabia.
}

Received: January 24, 2022

Accepted: February 24, $2022 \quad$ Online Published: March 2, 2022

doi:10.5430/wjel.v12n1p275

URL: https://doi.org/10.5430/wjel.v12n1p275

\begin{abstract}
The current study investigates some distinctive translation strategies applied in the translation of an article about the World Arabic Language Day from English into Arabic. By reviewing literature in that field, the number of studies searching the application of such strategies in translating website articles are few. The applicability of such strategies in the translation of website articles is an important point that is answered in the current study. The analysed document is an article issued by the United Nations Educational, Scientific and Cultural Organization (UNESCO) on $18^{\text {th }}$ December 2021 for the celebration of the Arabic Language Day internationally. The current website article is a sample of articles issued by international organisations in various official languages where English and Arabic are two of them. The researcher investigates the application of Baker's strategies for translation during the translation process. The current research proves that distinctive strategies for translation are applied during the translation process from English into Arabic in website articles genre to enhance comprehensibility. The study also indicates that applied strategies for translation do not change the meaning of the translated text in comparison to the source text. On the contrary, translation strategies enhance explicitness in translated texts.
\end{abstract}

Keywords: translation strategies, English-Arabic translation, cultural substitution, superordinate, translation universals

\section{Introduction}

'Translation' is a broad field that is described by many scholars. Blum-kulka (2000), Chesterman (2004) and Klaudy (2010) described translation as a piece of work that is usually more explicit than its original source. Vinay \& Darbelnet (1958/1995) described lexical characteristics in the translation process as being a stylistic translation technique that makes the target text more explicit in comparison to its implicit source text due to the situation or the context.

Studying strategies of expressing lexemes and conveying the message in the translation process is a phenomenon investigated in the field of linguistics. In translation as a field, linguists suggested numerous elements classified as translation strategies. The most important translation strategies are those defined by Mona Baker in 2011, known as Baker's taxonomy, which are a group of strategies for translation applied during the translation process. According to Owji (2013), Baker's taxonomy represents the popular and applicable strategies for translation professional translators apply while translating.

The researcher investigates the application of Baker's translation strategies in the translation process from English into Arabic to a website article issued by the United Nations Educational, Scientific and Cultural Organization (UNESCO).

\subsection{Statement of the Problem}

By reviewing the literature and studies searching the application of some strategies for translating website articles, the number of such studies is few. The researcher investigates the applicability of some strategies in the translation of a website article and their role in producing a clear and comprehensible translated text.

\subsection{Research Question}

Does the application of Baker's translation strategies while translating website articles from English into Arabic lead 
to an explicit sharing of information?

\subsection{Significance of the Study}

The importance of the study originates from its role in highlighting the role of Baker's (2011) translation strategies followed in translating website articles and producing clear translated texts. Identifying these strategies certainly helps translators perform their work and guides them about how to produce comprehensible translated versions of their work.

\subsection{Source of Linguistic Data}

The selected document for analysis is a website article issued on $18^{\text {th }}$ December 2021 by the UNESCO for celebrating the World Arabic Language Day. It is an important article because it reflects the importance of Arabic as an international language that is used worldwide. It also reflects how international institutions classify Arabic as a recognized language used for communication. The researcher investigates the application of common translation strategies to the translated version of the English website article titled: "World Arabic Language Day". Several reasons made the researcher chooses the current article for analysis. First, English and Modern Standard Arabic are two of the languages chosen for writing the article. The two languages are chosen because they are clear and standard languages used worldwide. Second, the translation of this article is performed through professional translators and revised many times to avoid mistakes before being published and read in an international website.

\section{Review of Literature}

\subsection{Translation and Its Strategies}

\subsubsection{Translation (Definition and Different Theories)}

Many scholars studied translation since it is an important field in linguistics. Eugene A. Nida is a famous scholar in that field who is known for his translation of the Bible. He proposed a theory about translation. He discusses the definition of translation in his theory. Nida \& Taber (1969) give a definition for the translation process and the establishment of an equivalent as the "closest natural equivalent".

The definition of translation is not fixed. There are numerous definitions of translation provided by various linguists. Shuttleworth \& Cowie (1997) and Larson (1998) state that translation undergo a change in form. This change includes a change in words, phrases, clauses, sentences, or paragraphs. The change occurs when the translator changes the form of the source language into the target or the receptor language form. William (2009) emphasizes the previous concept about the translation process.

Baker (2009) has a definition about translation. The definition is that translation is a process aiming for finding equivalence in meaning in the target language (TT). Baker (2018) explains that a good translator cannot start translating a text unless he or she reads it at least one time and finds a 'gist' of the message in the text he or she is translating. When the translator knows well the text he/she is translating, his/her role is to provide a translation that will transfer the cultural and linguistic features of the source text (ST) to the target text (TT).

Ran (2009) performs in his study about translation an analysis to Nida \& Taber's definition of translation from a philosophical point of view. He concludes that 'equivalence' as a concept, according to Nida \& Taber's definition, is not complete because the level of equivalence in their definition is not limited. Baker (2019) discusses the concept of equivalence at levels such as the word level and the textual, grammatical, and pragmatic levels. In other words, Baker talks about the hierarchical levels of "equivalence".

\subsubsection{Translation Strategies}

Operators of the translation process have been firstly introduced as 'translation procedure' which is the English translation for the terms 'procédé technique de la traduction ' introduced by Vinay and Darbelnet in 1958. The term 'translation procedure', introduced by them, means all the processes that are involved when translating from one language to the other. Vinay and Darbelnet intended by their theory to make it a global translation theory depends on presenting a whole text of equivalence gained from comparing and translating two languages. Vinay and Darbelnet's (1958/1995) translation procedures depend on three linguistic levels: morphosyntactic (agencement), lexical (lexique), and semantic (message).

Newmark uses Vinay and Darbelnet's term ' translation procedures' highlighting the difference between this term and the term 'translation methods' by stating: 'While translation methods relate to whole texts, translation procedures are used for sentences and the smaller units of language' (1988, p. 81). 
Mason (1994) in his discussion of 'translation techniques' does not reveal a difference between them and 'translation procedures', and 'translation methods'. Mason talks about translation strategies referring to them as 'translation procedures' where he mentions: 'A procedure is a method adopted to achieve a result. It is a way of proceeding in order to complete some activity' (1994, p. 63).

Baker (2011) discusses various approaches professional translators can apply while translation process. Owji (2013) calls the approaches Baker explained as 'translation strategies', used during the translation process, the taxonomy of Baker.

Sirilak (2014) discusses various useful translation strategies that can be applied when translating texts that are culturally bound. He stresses the point that translation "is not merely the rendering of the meaning between 'two languages', but a transfer from one culture to another" (2016, p. 29). Sirilak (2014) mentions four degrees of cultural transfer which are cultural transplantation, cultural borrowing, communicative translation and calque.

Kim \& Zhu (2019) also discuss the concept of 'translation strategies' and state that it became widespread among researchers studying the translation process. The term 'translation strategies' is used to refer to the operations and procedures the translator undergoes mentally while translating.

Concerning the studies conducted regarding translation strategies, Pujiastuti (2014) conducted a study describing translation strategies used by students of a study programme about accounting of Bengkulu University that are applied to the translation of abstracts from Bahasa Indonesia into English. Stepanova (2017) conducted a study that specifies the translation strategies or methods that a group of practicing lawyers and professional translators applied to overcome problems faced in the translation of legal terms. The conclusion of the study is that the students applied several translation methods and strategies to the translation of legal terminology. Rus and Harpa (2018) conducted a comparative study through some students belonging to "Petru Maior" University. The students mentioned numerous approaches and types of translation practices being applied according to the skills of the professional translator and the text type.

A forth study about translation strategies is performed by Junining \& Kusuma (2020). The study reveals how a news article applied translation strategies through the analysis of English Education students from Faculty of Cultural Studies (FCS) of Universitas Brawijaya (UB). The translation strategies being applied are based on Baker's (2011) taxonomy of translation strategies. The study reflects how the students applied the eight translation strategies while translating a news article. The percentage of repetition of these strategies is $(95 \%)$ for the strategy of using a more general word, (75\%) for paraphrasing using related words, and $(73 \%)$ for the strategy of cultural omission and submission. In comparison, the strategy of translation by illustration is applied by a percentage (31\%) for the whole article.

In relation to the previous studies mentioned above, the current study focuses on Baker's (2011) strategies for translation applied by professional translators in translating a website article from English into Arabic.

\section{Methodology}

Since translation strategies are numerous in relation to different linguists, the study investigates some strategies identified by Baker (2011) and decides whether they are applicable to website articles. The strategies are applied to the Arabic version of an English article. A qualitative analysis is conducted for identifying the applicability of the set of translation strategies and their role in conveying clear and explicit information.

\subsection{Data Collection and Sampling}

The collected data are a website article written at the UNESCO website in English and Arabic on the $18^{\text {th }}$ of December 2021. The English article is read paragraph by paragraph and each paragraph is compared to its Arabic counterpart. This is carried out to discover whether the translation techniques apply to the Arabic version and whether they influence the transfer of the message and information in the target text. Such remarks are classified in a separate paper according to their type. The source text part that is made explicit in the target text, by applying translation strategies, is underlined along with its Arabic counterpart for clarification.

\subsection{Tools for Analysis}

Baker's (2011) translation strategies, known as Baker's taxonomy, are adopted in the current study. This group of strategies is chosen because it is the most applicable set of strategies used by professional translators (Owji, 2013). The eight strategies are: Translation by a more general word (superordinate), translation by a neutral/ less expressive word, translation by cultural substitution, translation using a loan word plus explanation, translation by paraphrase using a related word, translation by paraphrase using unrelated word, translation by omission, and translation by 
illustration. The researcher discusses in the current study each strategy separately and supports her discussion with explanatory examples.

\section{Results and Discussion}

The researcher discusses in the current section the applicability of the specified strategies identified by Baker (2011) to a website article at the UNESCO website written for the celebration of the World Arabic Language Day titled: 'World Arabic Language Day' in 2021.

\subsection{Translation by a More General Word (Superordinate)}

In translation, this strategy is one of the common strategies and is considered successful when being used in most languages. Baker (2011) as well as Boase-Beier (2014) and Doherty (2017) discuss this strategy. They claim that applying this strategy enables the translator to simply translate the specific source-language word into a more general word in the target language. The strategy is also known as 'Lexical broadening'.

Mauranen \& Kujamäki (2004) and Nord (2005) mention that lexical broadening is a technique followed in translating texts where a more general meaning in the target text (TT) is used instead of a source text (ST) word of a specific meaning. Toury (2012) calls this process the process of generalization of meaning. The current strategy, according to Baker (2011), is clear in the following example:

Table 1. Translation by a More General Word (Superordinate)

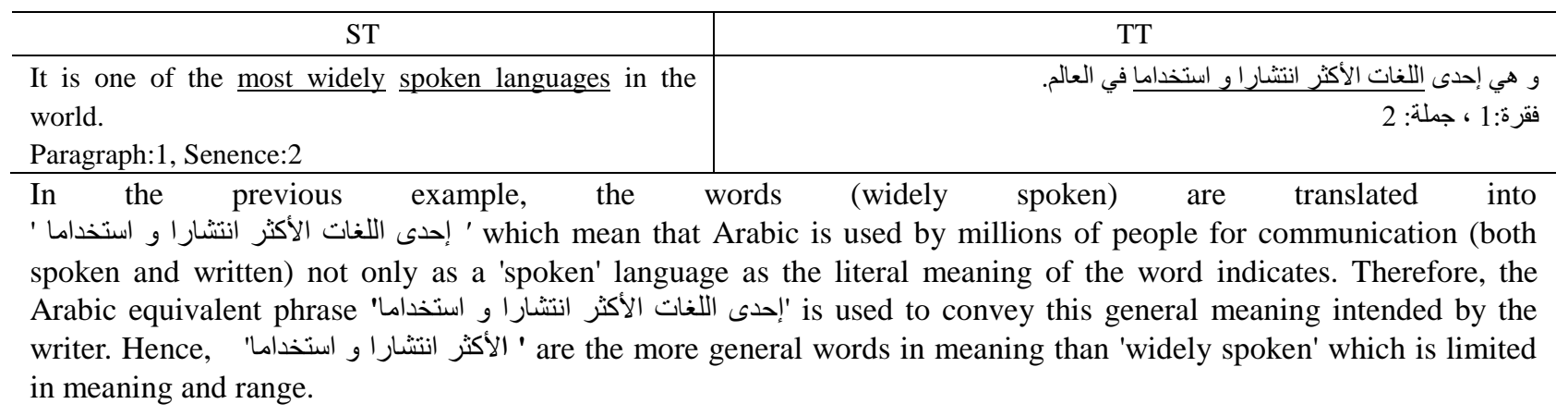

\subsection{Translation by a Neutral/ Less Expressive Word}

In translation, a translator can decrease and reduce the expressive meaning of a word according to current circumstances (Campbell, 1998). The use of the current strategy is a step for solving the problem of non-equivalence by making the word sound more common/ neutral through decreasing its expressive meaning. House $(2008,2015)$ talks about translation by narrowing as a similar strategy. Baker \& Saldanha (2009) discuss the same concept by explaining that translation by a neutral/ less expressive word is narrowing (specification). It is a process in the TT in which the chosen word has a narrow (or more specific) meaning in comparison to the ST word. According to Baker (2011), such a strategy is clear in the following example:

Table 2. Translation by a Neutral/ Less Expressive Word

\begin{tabular}{|c|c|}
\hline ST & TT \\
\hline $\begin{array}{l}\ldots \text { its history reveals the richness of its links with other } \\
\text { languages. } \\
\text { Paragraph:2, Sentence: } 2\end{array}$ & 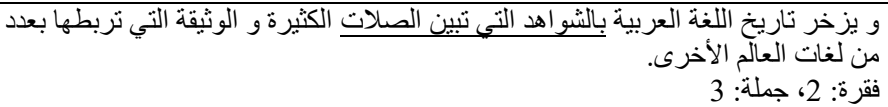 \\
\hline
\end{tabular}

In the current example, the word 'links' - which has the Arabic translation 'الشو/هد التي تبين الصلات includes in its literal sense the covering of all forms of links such as: the use of loan words and certain structures of foreign languages. Instead, it is narrowed in translation to mean 'الشواهـ: 'اهوان ' which is 'evidence for the existence of real links with other languages'. Therefore, 'الشواهد' is the less expressive word used in the translated text.

\subsection{Translation by Cultural Substitution}

Baker (2011) and Hassan (2014) discuss the strategy of translation by cultural substitution, which allows the translator to use a target language word to replace the expression which is culture specific. Hence, the item of the target language could have the same effect on the reader as the source item. Molina and Albir (2002) when talking about cultural substitution mention that there is a privilege in applying such a strategy which is that the reader can find what he could identify with in the TT (target text). By applying such a strategy, the choice of the translator shall depend on his skill of choosing what is appropriate in addition to the intention or purpose of the translation. A clear example of translation by Cultural Substitution according to Baker (2011) is the following: 
Table 3. Translation by Cultural Substitution

\begin{tabular}{|c|c|}
\hline ST & $\mathrm{TT}$ \\
\hline $\begin{array}{l}\text { The Arabic language is a pillar of the cultural diversity of } \\
\text { humanity. }\end{array}$ & 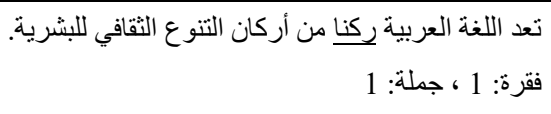 \\
\hline Paragraph: 1, Sentence: 1 & \\
\hline
\end{tabular}

The translator applies a cultural substitution technique to explain and specify the concept of the Arabic language as being a pillar of cultural importance in the history of human languages by stating "رعنا من أركان التنوع الثقافي could have used the Arabic words 'عامود من أعمدة' but he preferred to explain the concept with a word of a more illustrative impression and solid figurative meaning " Explanation by cultural substitution is used for making the meaning clear to the readers since this is a published website article for an international celebration where every word and concept should be clearly explained and specified. The Arabic translation is performed applying a lexical factor in choosing the translated word. This procedure is required for comprehension in the Arabic translation.

\subsection{Translation Using a Loan Word plus Explanation}

In translation, it is possible to translate a word just by mentioning the word itself followed by an explanation. The current strategy is a technique of translation where the translator can leave the source word as it is in the TT followed by a phrase for explanation. When the loan word is explained, it is possible to repeat the loan word in different places in the text (Stiegelbauer et al., 2016). Baker comments that there is no need to explain the loan word again because repetition may mislead the reader. A clear example for such a strategy is the following:

Table 4. Translation Using a Loan Word plus Explanation

\begin{tabular}{|c|c|}
\hline ST & TT \\
\hline $\begin{array}{l}\text { In the diversity of its forms, classic or dialectal, from oral } \\
\text { expression to poetic calligraphy, the Arabic language has } \\
\text { given rise to a fascinating aesthetic, in fields as varied as } \\
\text { architecture, poetry, philosophy and song. } \\
\text { Paragraph: } 2 \text {, Sentence: } 1\end{array}$ & 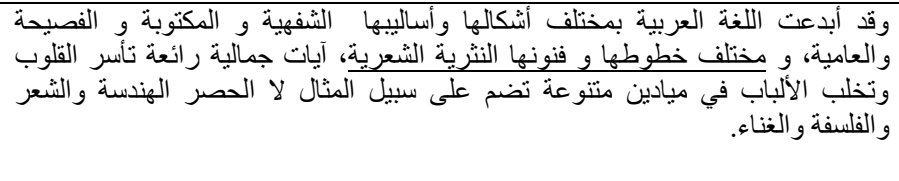 \\
\hline & فقرة: 3 ، جملة: 1 \\
\hline
\end{tabular}

The current example reveals that there is a foreign word 'calligraphy' that is mentioned in the English text and is translated into 'مختلف خطوطها' 'فن الخط' '. Thile it literally means translator explains what is meant by this expression 'poetic calligraphy' by saying 'مختلف خطوطها و فنونها النثرية الشعرية ' which is an explanation to the foreign expression 'calligraphy' in 'poetic calligraphy' that may not be clear to the Arab reader. The explanation through the use of parenthetical phrases after loan words is a syntactic feature required for comprehension in the Arabic translation. In the current example, the loan word is not mentioned in Arabic but its expalantion is being used.

\subsection{Translation by Paraphrase Using a Related Word}

The translator applies this strategy by choosing a related word in meaning to the source word to use in the target text (TT). In other words, this strategy is simply the replacement of the ST word with a TT synonym.

As El-Nashar (2016) highlights in his research, the idea of 'explanatory phrases' can be used as one of the techniques for explicitation which corresponds to the technique of paraphrasing using a related word strategy. The current case, according to Baker (2011), is clear in the following example:

Table 5. Translation by Paraphrase Using a Related Word

\begin{tabular}{|c|c|}
\hline ST & TT \\
\hline It gives access to an incredible variety of identities & وتتيح اللغة العربية الدخول إلى عالم زاخر بالتنوع بجميع أثكاله وصور وه، ومنها \\
\hline and beliefs and its history reveals the richness of its & تتوع الأصول و المشارب و المعتقدات. \\
\hline links with other languages. & فقرة: 2 ، جملة: 2 \\
\hline Paragraph: 2 , Sentence: 2 & \\
\hline \multicolumn{2}{|c|}{ 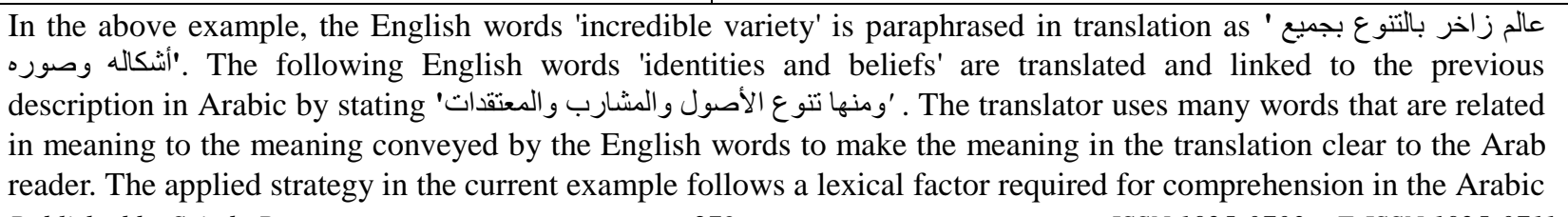 } \\
\hline Published by Sciedu Press & $79 \quad$ ISSN 1925-0703 E-ISSN 1925-0711 \\
\hline
\end{tabular}


translation.

\subsection{Translation by Paraphrase Using Unrelated Word}

It is used when the source word is not mentioned explicitly in the target text. Such a strategy is not recommended by Baker to be used frequently since the translation of one word in the ST might require the use of many words in the TT for explanation. The following example is a case in point.

Table 6. Translation by Paraphrase Using Unrelated Word

\begin{tabular}{|c|c|}
\hline ST & $\mathrm{TT}$ \\
\hline $\begin{array}{l}\text { It is one of the most widely spoken languages in the } \\
\text { world, used daily by more than } 400 \text { million people. } \\
\text { Paragraph: } 2 \text {, Sentence: } 2\end{array}$ & 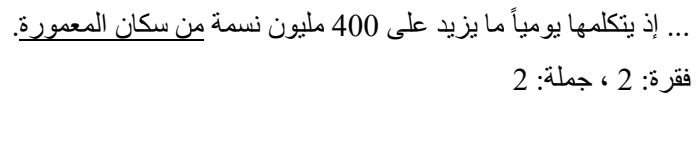 \\
\hline
\end{tabular}

The above example shows how the word 'people' is translated into Arabic as 'سكان الدعورة ' using unrelated words that explain a phrase that could be understood from the English text which is 'people around the world'. The translator did not translate '400 million people' into 'نسمة ' instead

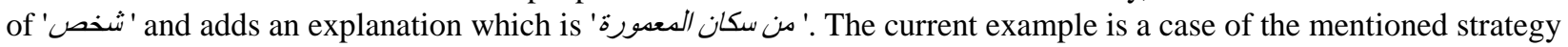
used to make the Arabic text clear to its reader and to reflect the great value of the Arabic language in the world.

\subsection{Translation by Omission}

It is a strategy in translation where the translator can omit a particular word or expression which seems unimportant for conveying the message in the TT. By applying such a strategy, the translated text would be very smooth in nature while being, sometimes, less expressive as highlighted by Baker. Sometimes the application of such a strategy in translation may lead to a possible loss of certain meanings in the TT. Therefore, this strategy is not recommended to be used frequently as Baker (2011) mentions. The current example reveals such a strategy:

Table 7. Translation by Omission

\begin{tabular}{l|c}
\hline \multicolumn{1}{c|}{ ST } & TT \\
\hline $\begin{array}{l}\text { World Arabic Language Day 2021: Arabic Language, } \\
\text { a bridge between civilisations }\end{array}$ & - اليوم العالمي للغة العربية لعام 2021: اللغة العربية والتواصل العضاري \\
- A subtitle & \\
\hline
\end{tabular}

While translating the current example, the translator omits the words 'bridge between civilisations' and uses a

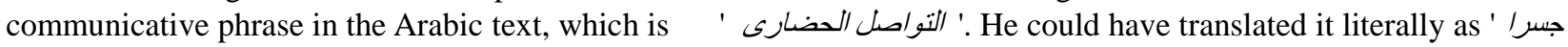
to make the subtitle attractive to the reader. He adds a phrase that did not affect the original meaning of the ST. On the contrary, the added phrase enriched the meaning and the translation, and made it attractive to the reader.

\subsection{Translation by Illustration}

It is a strategy helps the translator to overcome the problem of finding a proper equivalent for a specific item. The current strategy is mostly applied when referring to a physical entity. The famous example of this strategy is the use of a picture of a tagged tea bag to explain the concept of a tagged entity instead of mentioning long description that might not reflect what is meant exactly.

The translator, in the current strategy, uses the same picture found in the English article to attract the reader to this article if the reader wants to know immediately what this article is about. The picture being used is a group of Arabic letters and words used as a key to the content of the article in addition to an Arabic title: 'البيوم العالدى للغة العربية. The illustration, used here, makes the reader decides immediately either to read the article since it is of interest for him, or leave reading it.

\subsection{Major Findings}

By investigating the application of Baker's translation strategies to an English text which is a website article about the Arabic language and its Arabic translated version, the researcher finds that the strategies apply to the Arabic version. The strategies are used naturally in the translation process resulting in a clear and meaningful text. Translation strategies are applied in the translation of website articles. They are a universal phenomenon and this finding agrees with the previous researches conducted by Pujiastuti (2014), Stepanova (2016), Rus and Harpa (2018) and Junining \& Kusuma (2020). When Baker's (2011) translation strategies applied, they give a full text with clear 
and comprehensible information.

The research reflects that the application of the translation strategies did not lead to a change in the TT meaning in comparison to the original meaning in the ST. On the contrary, the transferred meaning in the target text (TT) is clear, meaningful and explicit. Translation strategies did not also create redundant long sentences in the TT. As an example, وهي إحىى اللغات الأكثر و the strategy of translation by a more general word (superordinate) makes the translator chooses to express the universality of Arabic (spoken and written) more than being only a universal spoken language. These findings answer the research question which is: "Does the application of Baker's translation strategies while translating website articles from English into Arabic lead to an explicit sharing of information?"

The researcher supports the importance of applying Baker's (2011) translation strategies as a technique for getting a better and clear translation, and agrees with the point of view that translation strategies are multiple choices techniques used in translation for having comprehensible Arabic texts.

\section{Conclusion}

The performed analysis benefits from Baker's (2011) translation strategies, which are universal in reaching comprehensible translated texts. The analysis shows that translation strategies apply to the translation of website articles as a genre in comparison to other genres. The researcher investigates the eight strategies followed and applied during the translation process. The researcher reveals that the translator uses Baker's translation strategies due to lexical or syntactic reasons required by the target language (TL) rules.

Baker's strategies for translation reflect various phenomena. Concerning translation by paraphrase using unrelated word, the researcher notices that the Arabic clause is an explanation for words understood by context though not mentioned explicitly in the ST. Translation by a neutral/ less expressive word is an intended strategy in the translation of the ST for the purpose of clarity and restriction in the TT.

The analysis of the different strategies for translation reveals when it is necessary to apply them for having clear meaning along with natural Arabic translation.

\section{Recommendations for further study}

The researcher recommends that future researches could investigate the applicability of translation strategies to literary works or media means such as news articles and magazines. Translation strategies can be also applied to scientific researches that are translated into Arabic.

\section{About the Author}

Dr. Dalia Abdelwahab Massoud Abdelwahab is an assistant professor of linguistics and translation. Her areas of research interest include but not limited to discourse analysis, syntax, semantics and translation. ORCID: https://orcid.org/0000-0003-1499-6366

\section{References}

Baker, M. (2011). In other words: A coursebook on translation (2nd ed.). London and New York: Routledge. https://doi.org/10.4324/9780203832929

Baker, M. (2018). In other words: A coursebook on translation (3rd ed.). London and New York: Routledge. https://doi.org/10.4324/9781315619187

Baker, M. (2019). Translation and conflict: A narrative account (2nd ed.). London and New York: Routledge. https://doi.org/10.4324/9780429438240

Baker, M. (Ed.). (2009). Translation studies (1st ed.). London and New York: Routledge. https://doi.org/10.4324/9780203872062

Baker, M., \& Saldanha, G. (Eds.). (2009). Routledge encyclopedia of translation Studies. London and New York: Routledge.

Blum-Kulka, S. (2000). Shifts of cohesion and coherence in translation. In L. Venuti (Ed.), The translation studies reader (pp. 298-313). London and New York: Routledge.

Boase-Beier, J. (2014). Translation and the representation of thought: the Case of Herta Muller. Language and Literature, 23(3), 213-226. https://doi.org/10.1177/0963947014536503

Campbell, S. (1998). Translation into the second language. London and New York: Longman.

Chesterman, A. (2004). Beyond the particular. In A. Mauranen, \& P. Kujamäki, (Eds.), Translation Universals Do 
they exist? (pp. 33-50). Amsterdam: John Benjamins Publishing Company. https://doi.org/10.1075/btl.48.04che

Doherty, S. (2017). Issues in human and automatic translation quality assessment. In D. Kenny (Ed.), Human issues in translation technology (pp. 131-148). London and New York: Routledge.

El-Nashar, M. (2016). Explicitation techniques in English-Arabic translation: A linguistic corpus-based study. Arab World English Journal (AWEJ), 7(3), 317-335. https://doi.org/10.24093/awej/vol7no3.23

Hassan, B. A. (2014). Between English and Arabic: A practical course in translation (Unabridged ed.). Cambridge: Cambridge Scholars Publishing.

House, J. (2008). Beyond intervention: Universals in translation? Trans-kom, 1(1), 6-19.

House, J. (2015) Translation quality assessment: Past and present. London: Routledge. https://doi.org/10.4324/9781315752839

Junining, E., \& Kusuma, V. A. M. (2020 ). Translation strategies for translating a news article. LiNGUA, 15(1), 1-15. https://doi.org/10.18860/ling.v15i1.9562

Kim, K. H., \& Zhu, Y. (Eds.). (2019). Researching translation in the age of technology and global conflict: Selected works of Mona Baker (1st ed.). London and New York: Routledge. https://doi.org/10.4324/9780429024221

Klaudy, K. (2010). Specification and generalisation of meaning in translation. Meaning in translation, 19, 81- 95.

Larson, M. L. (1998). Meaning-based translation: A guide to cross-language equivalence. USA: University Press of America.

Mason, I. (1994). Techniques of translation revised: a text linguistic review of borrowing and modulation. In A. H. Albir (Ed.), Translation techniques revisited: A dynamic and functionalist approach (pp. 61-72). Spain: Universitat Jaume I.

Mauranen, A., \& Kujamäki, P. (Eds.). (2004). Translation universals do they exist? Amsterdam: John Benjamins Publishing Company. https://doi.org/10.1075/btl.48

Molina, L., \& Albir, A. (2002). Translation techniques revisited: A dynamic and functionalist approach. Meta: Journal des traducteurs Meta:/Translators' Journal, 47(4), 498-512. https://doi.org/10.7202/008033ar

Newmark, P. (1988). A textbook of translation. New York: Prentice Hall.

Nida, E., \& Taber, C. (1969). Theory and practice of translation. UK: United Bible Societies.

Nord, C. (2005). Text analysis in translation: Theory, methodology, and didactic application of a model for translation-oriented text analysis. The Modern Language Journal, 76(4), 581-582. https://doi.org/10.2307/330103

Owji, Z. (2013). Translation strategies: A review and comparison of theories. Translation Journal, 17(1), 1-13.

Pujiastuti, S. (2014). A survey on translation strategies used by accounting study program students in translating undergraduate thesis abstracts [Unpublished M.A. dissertation]. University of Bengkulu. Retrieved from http://repository.unib.ac.id/id/eprint/8288

Ran, S. (2009). Philosophical interpretation on E. A. Nida's definition of translation. Asian Social Science, 5(10), 1-16. https://doi.org/10.5539/ass.v5n10p44

Rus, D., \& Harpa, E. (2018). Technical vs. general translation practices and methods: a comparative study. Procedia Manufacturing, 22, 840-847. https://doi.org/10.1016/j.promfg.2018.03.119

Shuttleworth, S., \& Cowie, M. (1997). Dictionary of translation studies. UK: Manchester.

Sirilak, K. (2014). The analysis of translation techniques used in translation of Harry Potter and the Prisoner of Azkabun in the Thai language [Unpublished M.A. dissertation]. Thailand: The School of Language and Communication, Nation Institute of Development Administration. Retrieved January 1, 2022, from http://library1.nida.ac.th/termpaper6/lang/2014/20093.pdf

Stepanova, V. V. (2017). Translation strategies of legal texts: experimental approach. Procedia - Social and Behavioral Sciences, 2, 180-190. https://doi.org/10.1016/j.sbspro.2017.02.190

Stiegelbauer, L., Schwarz, N., \& Husar, D. (2016) Three translation model approaches. Studii de ştiinţăşiculturăa, 12(3), 45-50.

Toury, G. (2012). Descriptive translation studies - and beyond (Revised ed.). Amsterdam: John Benjamins Publishing Company. https://doi.org/10.1075/btl.100 
Vinay, J. P., \& Darbelnet, J. (1958/1995). Comparative stylistics of French and English: A methodology for translation (Vol. 11). Amsterdam: John Benjamins Publishing Company. https://doi.org/10.1075/btl.11

Williams, M. (2009) Translation quality assessment. Mutatis Mutandis, 2(1), 3- 23.

World Arabic Language Day (2021, December 18). UNESCO website. Retrieved from https://en.unesco.org/commemorations/worldarabiclanguageday

استراتيجيات الترجمة المطبقة في الترجمة من الإنجليزية إلى العربية: دراسة لمقالة في موقع الكترونى على شبكة الإنترنت

نبذة مختصرة

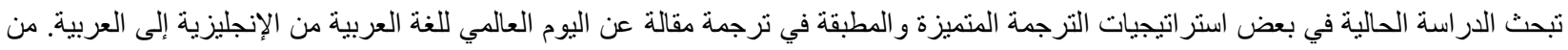

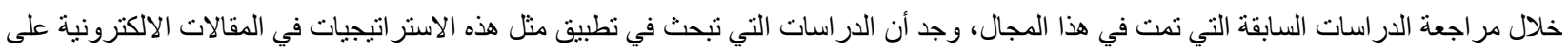
الانترنت تعد قليلة. و تعتبر قابلية تطبيق مثل هذه الاستراتيجيات في ترجمة المقالات الالكترونية نقطة مهمة يتم شرحها و تحليلها في الدراسة الحالية. إن فئل

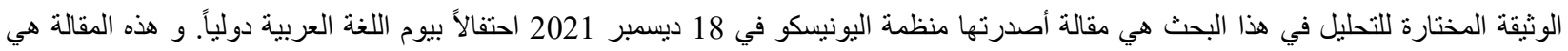

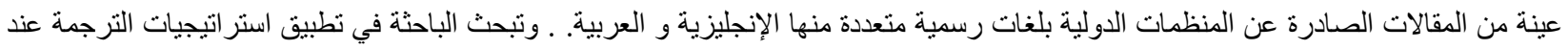

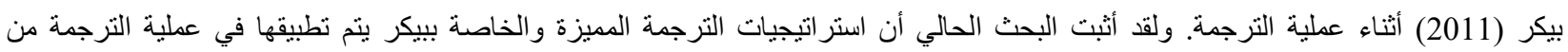

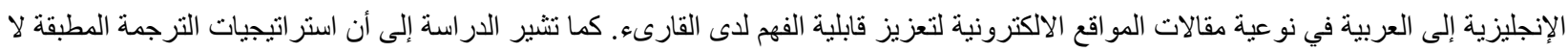

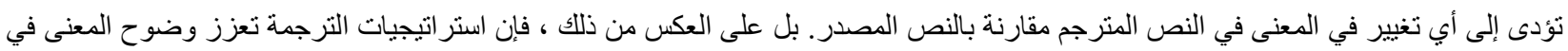
النصوص المترجمة.

الكلمات المفتاحية: استراتيجيات الترجمة ، الترجمة من الإنجليزية إلى العربية ، الاستبدال الثقافي ، المستوى الأعلى للكلمة ، الثوابت العالمية في الترجمة.

\section{Copyrights}

Copyright for this article is retained by the author(s), with first publication rights granted to the journal.

This is an open-access article distributed under the terms and conditions of the Creative Commons Attribution license (http://creativecommons.org/licenses/by/4.0/). 